\title{
ENGINEERING STUDY ON PLANTERS FURROW OPENER FOR ACCURATE PLANTING
}

\section{ELSHABRAWY, H $^{1} \quad$ R. M. SALIM ${ }^{2} \quad$ W. M. Abdel-Salam ${ }^{3}$ \\ ABSTRACT}

In order to increase agricultural production, the government had realized not only new techniques in agricultural field, but also modified and improved the capability of the available techniques. In fact, using planters and seed-drills in sowing process is considered one of the most important agricultural operations, to achieve the final aim from applied mechanization in sowing seeds. Soil collapsing phenomenon behind the furrow opener of planter, before deposit seeds, is considered one of the problems encountered in plants, because it does not only cause un regular seed depth, but also it strongly caused a bad effect on seed germination ratio and final yield.

\section{Therefore, the aims of this research are:}

(1) To study soil collapsing phenomenon behind the planters furrow opener, this causes high scale variety in sowing seed depth.

(2) To determine the effect of irregular sowing seed depth on germination ratio and the lateral scattering of seeding plants.

(3) To develop and design a new furrow opener for minimizing soil collapsing phenomenon behind the furrow opener of planters, and controlling the furrow depth for improving the contact area between seeds and soil particles.

The tested factors were angle of ridge $(A), A_{1}\left(20^{\circ}\right), A_{2}\left(30^{\circ}\right), A_{3}\left(40^{\circ}\right)$ and $A_{4}\left(50^{\circ}\right.$, ) Planting forward speed $(F), \quad\left(F_{1}(3 \mathrm{~km} / \mathrm{h}),(3.5 \mathrm{~km} / \mathrm{h})\right.$ and $(4 \mathrm{~km} / \mathrm{h})$ and The depth of planting $(d):, d_{1}(2 \mathrm{~cm}), d_{2}(3 \mathrm{~cm}), d_{3}$ $(4 \mathrm{~cm})$ and $d_{4}(5 \mathrm{~cm})$. The results showed that the highest germination ratio of plants $(99.1 \%)$ was recorded at the lowest forward speed $(3 \mathrm{~km} / \mathrm{h})$, and the highest depth of planting $(d 4=5$ $\mathrm{cm}$.) for furrow opener $\left(50^{\circ}\right.$ angle of ridge $)$, while the lowest

\footnotetext{
1 - Professor. of Agricultural Engineering, Faculty of Agriculture, Mansoura University

2 - Senior Researcher of Agricultural Engineering, Agric. Eng. Res. Institute

3- Agricultural Engineer
} 
germination plants ratio (92.7\%) was gained at the highest planting speed of $(4.5 \mathrm{~km} / \mathrm{h})$ and the lowest depth of planting $\left(d_{1}=2 \mathrm{~cm}\right.$.) for furrow opener $\left(20^{\circ}\right.$ angle of ridge).

\section{INTRODUCTION}

$\mathrm{P}$ lanting machine furrow openers are considered very important to control seeds placement and soil depth. In general, a furrow opener cuts a furrow and allows seeds or seedlings to be deposited before being partially covered with soil. The types of furrow openers used vary with soil and operating conditions. The common types of furrow openers used for conventional tillage are hoe, shovel, shoe, runner, single disc, double disc, chisel and inverted $\mathrm{T}$ shape furrow openers. Sanchez-Giron, Ramirez, Litago and Hernanz (2004) three different furrow openers, working in the same manner as they were mounted on commercial small grain drills offered by a drill manufacturer, were compared. The chisel-type furrow opener (FO1) had a width of $48 \mathrm{~mm}$, a curvature radius of $166 \mathrm{~mm}$, a total length of 236 $\mathrm{mm}$ and a rake angle of $50^{\circ}$. The reversible non-winged combine point furrow opener (FO2) had a width of $40 \mathrm{~mm}$, two points, with a wedge angle of $65^{\circ}$ and $70 \mathrm{~mm}$ in length each of them, a total length of $216 \mathrm{~mm}$ and a rake angle of $112^{\circ}$. Finally, the modified Suffolk type furrow opener (FO3) had a width of $40 \mathrm{~mm}$, a total length of $160 \mathrm{~mm}$ and a rake angle of $112^{\circ}$. Vamerali, Bertocco and Sartori (2005) A new WideSweep Opener (WSO) with which the no-till air seeder Cerere (Techno agricola, Udine, Italy) has been equipped. The WSO has a straight axis, ending with a front chisel and two rear side $18-\mathrm{cm}$ wide coulters, which are slightly angled towards the direction of work and curved upwards $\left(90^{\circ}\right)$ in their final part (25 mm high). The front chisel cuts soil 25-30 $\mathrm{mm}$ deeper than the coulters. Seed delivery to each unit is through a single pneumatic tube from the centralized volumetric metering system, which allows the seeder to assume a certain degree of polyvalence. Although various types of deposition (i.e., row spacing) can be set, in our field trial - as the first test of this prototype opener - maize was sown in rows $0.45 \mathrm{~m}$ apart, a distance commonly used in the experimental site. Karayel and Ozmerzi (2006) Shoe and hoe-type furrow openers were 
from grey cast iron, with cutting edge chilled to increase hardness and wear resistance. A pair of mild steel wings was welded to either side of shoe and hoe openers to complete the assembly. The single and double disc-type furrow openers were designed and fabricated from high-carbon steel plates $3.5 \mathrm{~mm}$ thickness. Also he added that furrow opener type had significant effects on sowing depth. Average sowing depth was significantly higher for hoe and single disc furrow openers as compared to shoe and double disc furrow openers for watermelon sowing. Mean sowing depth was maximum in the case of hoe-type furrow opener for maize sowing. While the most uniform sowing depth was obtained for shoe-type furrow opener, the least uniform was obtained for hoe-type furrow opener. Lateral seed scatter was significantly lower in the case of shoe and double disc furrow openers compared with the hoe and single disc furrow openers for maize sowing. Deviation was minimum in the case of shoe-type furrow opener for watermelon sowing. Karayel (2009) used two different types of furrow openers (hoe and double disc), one furrow opener on one row unit and the second furrow opener on another row unit, on the two-row seeder.

\section{MATERIAL AND METHODS}

To achieve the purpose of this study, it was necessary to construct new furrow openers with different variables, to minimize soil collapsing phenomenon behind the furrow opener of planters, and on the other hand press the furrow sides and bottom to improve the contact area between seeds and soil particles.

\section{Preliminary Experiments}

Laboratory tests were carried out to investigate four different factors. These factors were believed to have very important effect on furrow profile and height of collapsed soil in the furrow bottom. These factors were:

1) Angle of ridge:Four furrow openers were casted with four different angels $\quad\left(20^{\circ} \mathrm{A}_{1}, 30^{\circ} \mathrm{A}_{2}, 40^{\circ} \mathrm{A}_{3}\right.$ and $\left.50^{\circ} \mathrm{A}_{4}\right)$ as shown in Figure (3.1).

2) Cartage forward speed: $\left(0.8 \mathrm{~F}_{1}, 1 \mathrm{~F}_{2}, 1.2 \mathrm{~F}_{3}\right.$ and $\left.1.4 \mathrm{~F}_{4} \mathrm{~m} / \mathrm{s}\right)$. 
3) Height of wings: Three heights of wings for the four furrow openers $\left(3.5 h_{1}, 4 h_{2}\right.$ and $\left.4.5 h_{3} \mathrm{~cm}\right)$.

4) Depth of planting: $\left(2 d_{1}, 3 d_{2}, 4 d_{3}\right.$ and $\left.5 d_{4} \mathrm{~cm}\right)$.

\section{Experimental Equipments:}

\section{Source of power}

A 125 H.P John Deere tractor was used for the experimental work.

\section{Implement of soil-bed preparation}

The preparation of seed-bed included chiseling the field twice in perpendicular directions $(20 \mathrm{~cm}$. depth), followed by disk harrowing and leveling by mounted scraper.

\section{Mould board plow implement}

The plow used for soil preparation in this study was Mould board plow consists of five bottoms (Kevernland model).

\section{The planter}

The experimental area was planted using six rows planter (AMAZONE) model

\section{Eloped furrow opener}

To prevent soil collapsing behind the conventional furrow openers, a modification in the construction of furrow opener was developed and evaluated. The developed furrow opener was produced at the Modern Workshop for metal turning, Meet Ali, Dakahlia. It consists of two sides with dimensions of $(41 \times 9 \mathrm{~cm})$ every side provided with hitching holes to connect the sides with two wings of (37 $\mathrm{cm}$ length and $7 \mathrm{~cm}$ width) to control of depth.

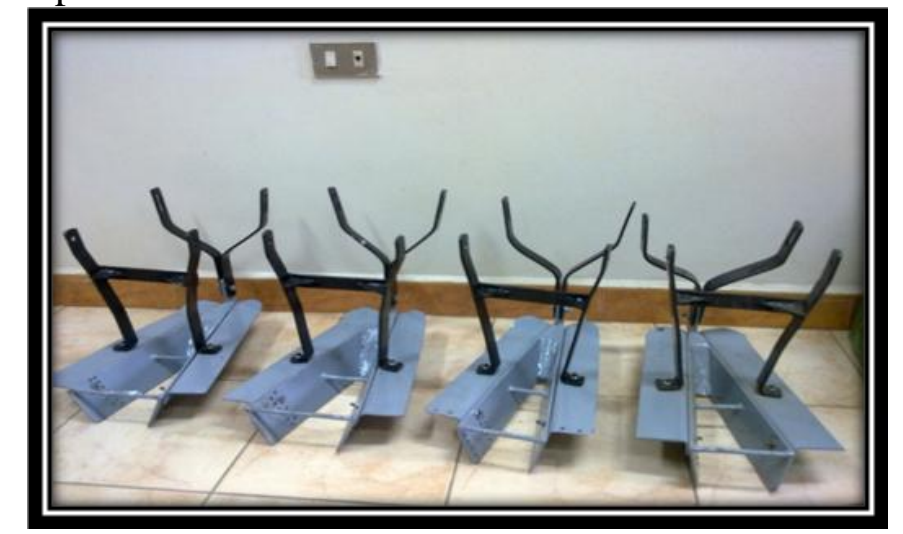

Fig. (1): Modified furrow openers with four angles. 


\section{The Experimental Procedure:}

\section{The selected treatments}

The effectiveness of the three developed furrow openers were compared under the effect of three chosen geometrical parameters:

1- Angle of ridge (A): As mentioned before in the preliminary tests on the angle of ridge were $\left(20^{\circ} \mathrm{A}_{1}-30^{\circ} \mathrm{A}_{2}-40^{\circ} \mathrm{A}_{3}-50^{\circ} \mathrm{A}_{4}\right)$.

2- Planting forward speed $(\mathbf{F})$ : Four planting forward speeds were used: $\left(F_{1}=3 \& F_{2}=3.5 \& F_{3}=4 \& F_{4}=4.5\right) \mathrm{km} / \mathrm{h}$.

3- The depth of planting (d): The depth of planting could be adjusted by lifting the furrow opener with respect to depth adjusting wheel, and consequently with respect to the fixed opener share. The opener share was fixed in the planter at $\left(2 d_{1}\right.$, $3 d_{2}$ and $\left.4 d_{3}\right) \mathrm{cm}$.

The field experiments were carried out during Zea maize planting.
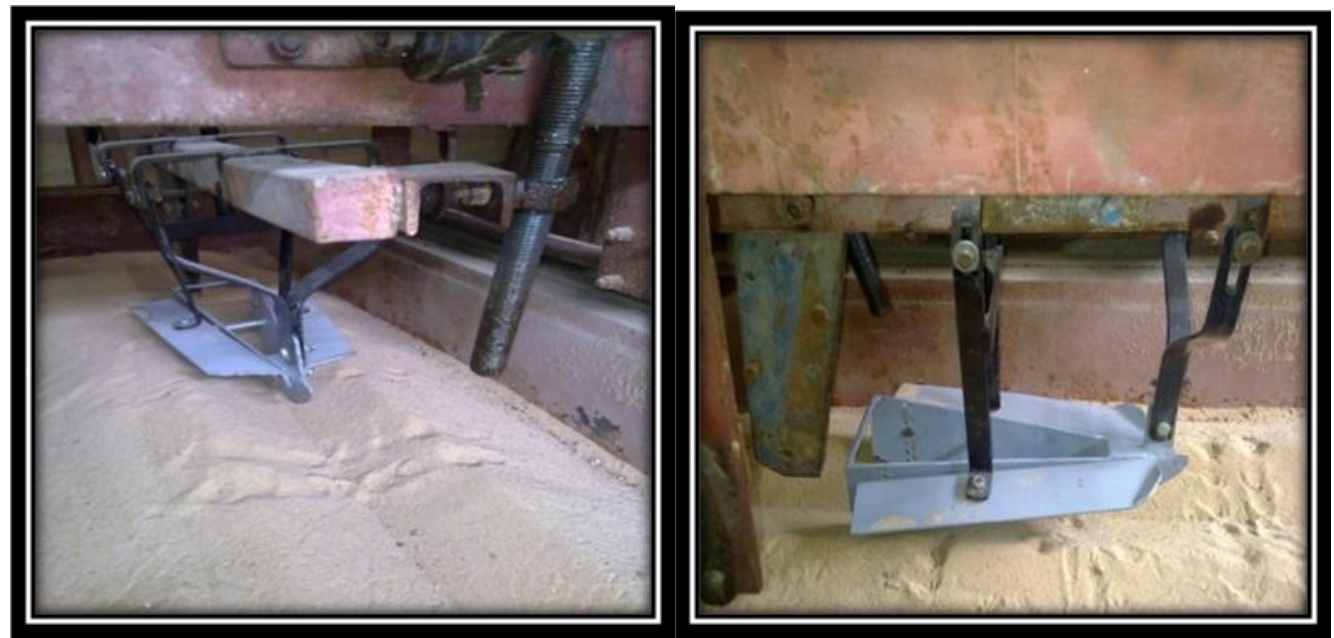

Fig. (2): Developed furrow opener during laboratory tests.

\section{Field measurements}

Furrow cross sectional areas (A) and profiles:

The furrow cross sectional area was measured directly after each pass using a profile - meter where the following equation was applied according to Abo - Habaga (1990) 


$$
\mathrm{A}=\frac{\Delta \mathrm{L}}{2}(\mathrm{a}+2 \mathrm{~b})
$$

\section{Where}
A $=$ Total cross - sectional area.
$\mathrm{mm}^{2}$
$\Delta \mathbf{L}=$ Constant horizontal distance.
$\mathrm{mm}$
$\mathbf{a}=$ Sum. of first and last ordinates.
$\mathbf{b}=$ Sum. of all ordinates excluding the first and last ones. $\mathrm{mm}$ The ordinates and furrow cross - section profile were measured and drawn by using the profile-meter shown in Figure (3.3).

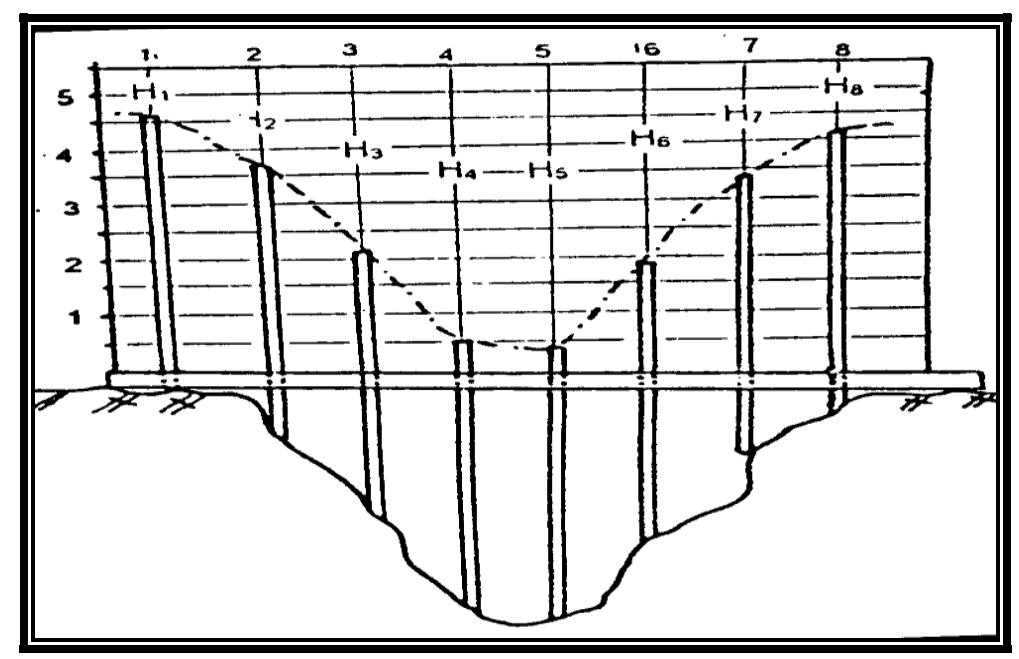

Fig. (4): The profile-meter used for determine the furrow crosssection profile and the ordinates length.

The height of collapsed soil in the furrow bottom $(\mathrm{H})$ :

To determine the height of the collapsed soil in the furrow bottom $(\mathrm{H})$, the actual furrow depth after soil slippage $\left(\mathrm{H}_{2}\right)$ was measured, where $\left(\mathrm{H}_{1}\right)$ is the furrow depth $\mathrm{mm}$. and $(\mathrm{H} \%)$ value was estimated by using the equation compatible by Abd-Alla (1999)

H $=\mathrm{H}_{1}-\mathrm{H}_{2} \mathrm{~mm}$ $3-2$

$\mathbf{H} \%=\mathrm{H} / \mathrm{H}_{1} \times 100$ 
Where

$\mathbf{H \%}=$ Height of turned soil as a percentage from press wheel or traditional opener depth.

To determine the height of turned soil in the furrow bottom $(\mathrm{H})$ for the traditional opener (shoe type), the opener depth was fixed at $4 \mathrm{~cm}\left(\mathrm{H}_{1}\right)$. The actual furrow depth $\left(\mathrm{H}_{2}\right)$ was measured and $(\mathrm{H})$ value was estimated using the previous equation.

\section{Plants lateral distribution around the row centerline:}

To determine the cross scattering of seeds around the rows, the distribution for the plants around the row centerline was determined 15 days after planting and first irrigation. The distribution was estimated by relating the number of plants at different lateral distances from the row center to the total number of plants at ten meters along of the row. The frequency distribution curves were employed for expressing this relationship for each experiment.

\section{The germination ratio of plants $(G)$}

The germination ratio of plants was calculated after 15 days from sowing and irrigation, the germination ratio was estimated according to the following formula (Abd-Alla, 1999),

$$
G=\frac{N}{S} \times 100
$$

\section{Where}

$\mathrm{N}=$ Number of plants per ten meters along the sowing row.

$\mathrm{S}=$ Number of delivered seeds per ten meters along the row. The value of (S) was calculated during the field calibration of the planter.

\section{RESULTS AND DISCUSSION}

\section{The Preliminary Experiments:}

This group of experiments were conducted to study the cross section profiles and the cross sectional areas for the four furrow openers on three 
depths and three height of wings at four forward speeds. From these experiments it can be found out which furrow opener was have the perfect profile.

In general, the Preliminary experiments data indicated the possibility of reaching the suitable planting depth by all furrow openers under study during field experiments due to the height of furrow opener wings.

\section{Field Experiments:}

This study was conducted in order to develop a new furrow opener to overcome the problem of the lateral scattering, the longitudinal scattering and soil collapsing phenomenon associated with the traditional furrow openers of planters also, to select one of the four developed furrow openers. The experimental work was carried out during sowing Zea maize. The measurements of furrow cross section profile, furrow cross section area, height of the collapsed soil in the furrow bottom, the lateral scattering of seeds and germination ratio of plants were assessed.

\section{Furrow section area and furrow cross-section profile}

The furrow cross sectional area (A) and the profile of the obtained furrow were calculated after the passing of furrow opener and before seed covering. To estimate the furrow cross section shape, all ordinate measurements were replicated ten times and the average values were calculated.

All furrow openers gave furrow profile correspondent to its angle size, but the traditional furrow opener caused non-organized symmetrical profile on the traverse direction of furrow. On the other hand, the increment in forward speed caused a decrease in furrow depth and increase in furrow width. This trend may be attributed to increasing the forward speed encourage the increase in height of the collapsed soil in the furrow.

\section{Height of collapsed soil in the furrow bottom}

The height of collapsed soil in the furrow bottom is considered as one of the most important measurements to evaluate the performance of planter furrow opener. Therefore, a comparative study between the four developed furrow openers and conventional opener (shoe type) were run. 
The results are showed that increment of planting speed caused an increase in collapsed soil height (little furrow depth).

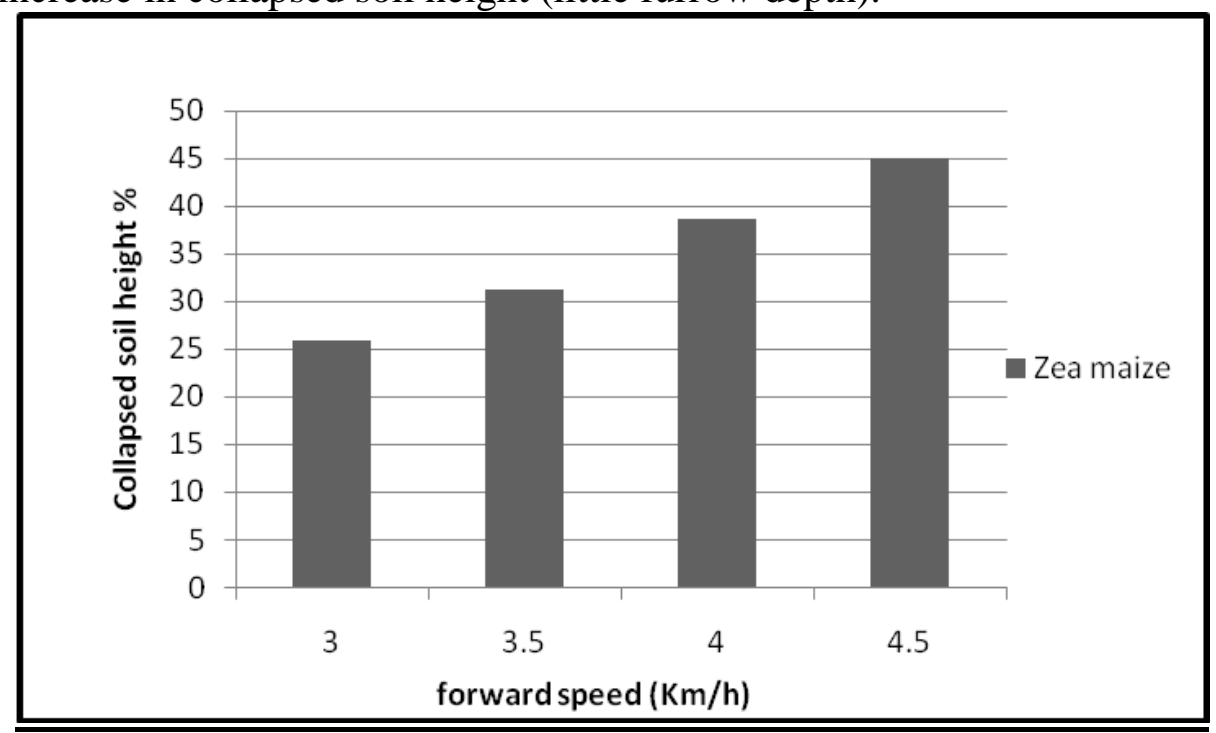

Fig. (5): The relationship between forward speed and collapsed soil height $\%$ for traditional furrow opener.

\section{The lateral scattering of seeds (L.S)}

The results graphically in figs. 5, 6, 7 and 8) one can said that, increasing the tractor forward speed causes an increase in the lateral scattering of seeds (L.S); this is due to the increase in planter vibration at high forward speed. Increasing the furrow opener height of wings led to decrease in seed scattering around the row centerline. Because the increase in the furrow depth improves the furrow structure and causes more compaction to the furrow bottom and gives a good seedbed. The angle of ridge of the furrow opener recorded the highest factor affecting the lateral scattering of seeds (L.S) around the row centerline. So, the $50^{\circ}$ angle of ridge is considered the best because it forms the deepest furrow. One can noticed that, the lateral scattering has an indirect proportional with planting depth and angle of ridge. On the other hand the lateral scattering has a direct proportional with tractor forward speed. This may be due to increasing tractor forward speed caused scattering of corn seeds that resulting increment of lateral scattering and vice versa at increasing depth and angle of ridge. 

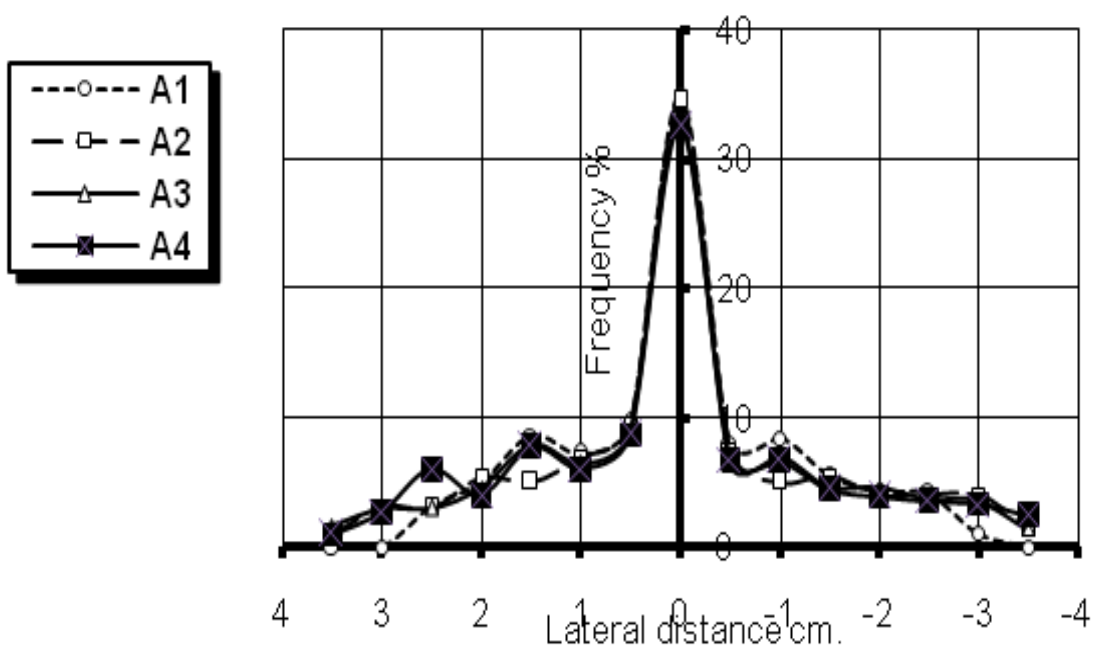

$\mathrm{Fig}(5$ ). Plant distribution around the row at center line (lateral scatering) for $\mathrm{F} 1$ and $\mathrm{d} 5$
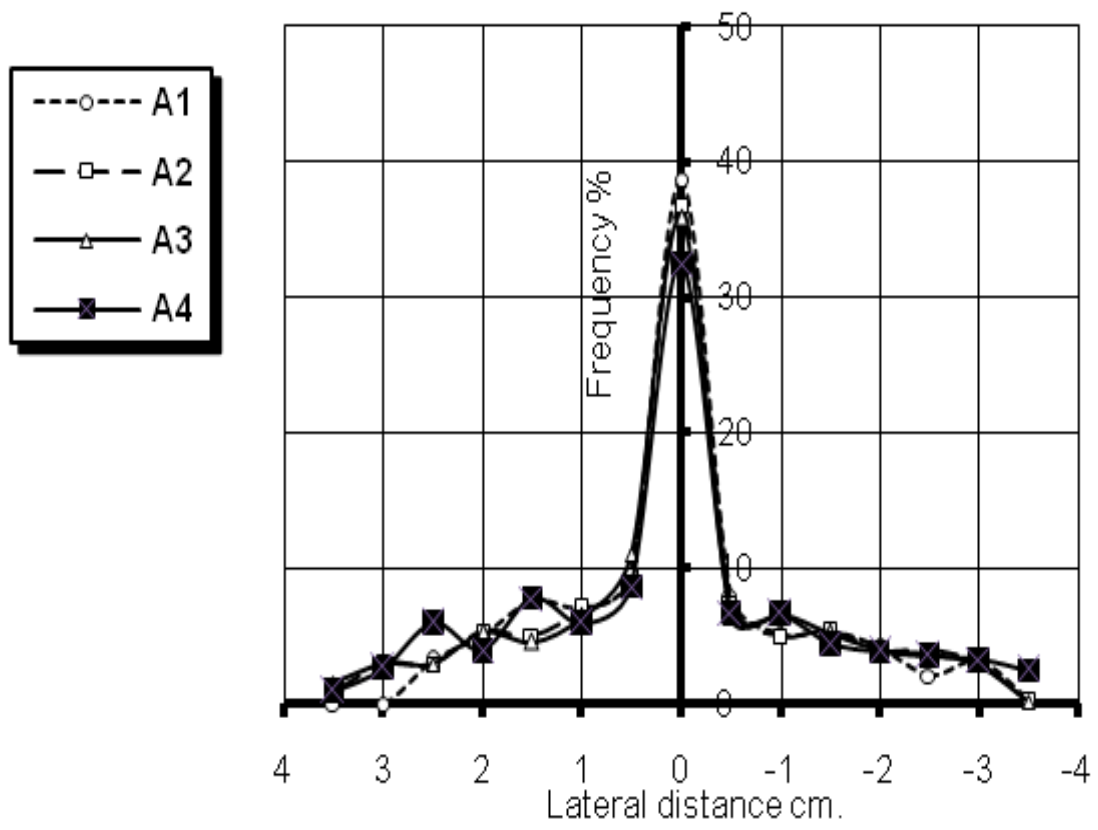

Fig ( 6 ). Plant distribution around the row at center line (lateral scatering) for $\mathrm{F} 2$ and $\mathrm{d} 5$ 

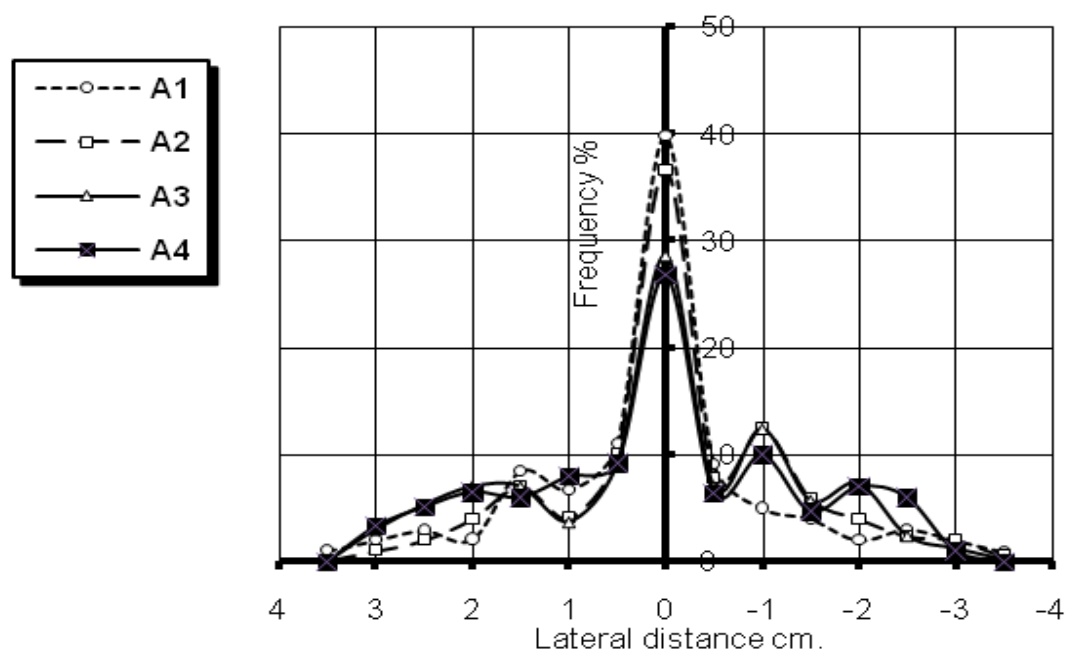

Fig (7). Plant distribution around the row at center line (lateral scatering) for $F 3$ and $d 5$

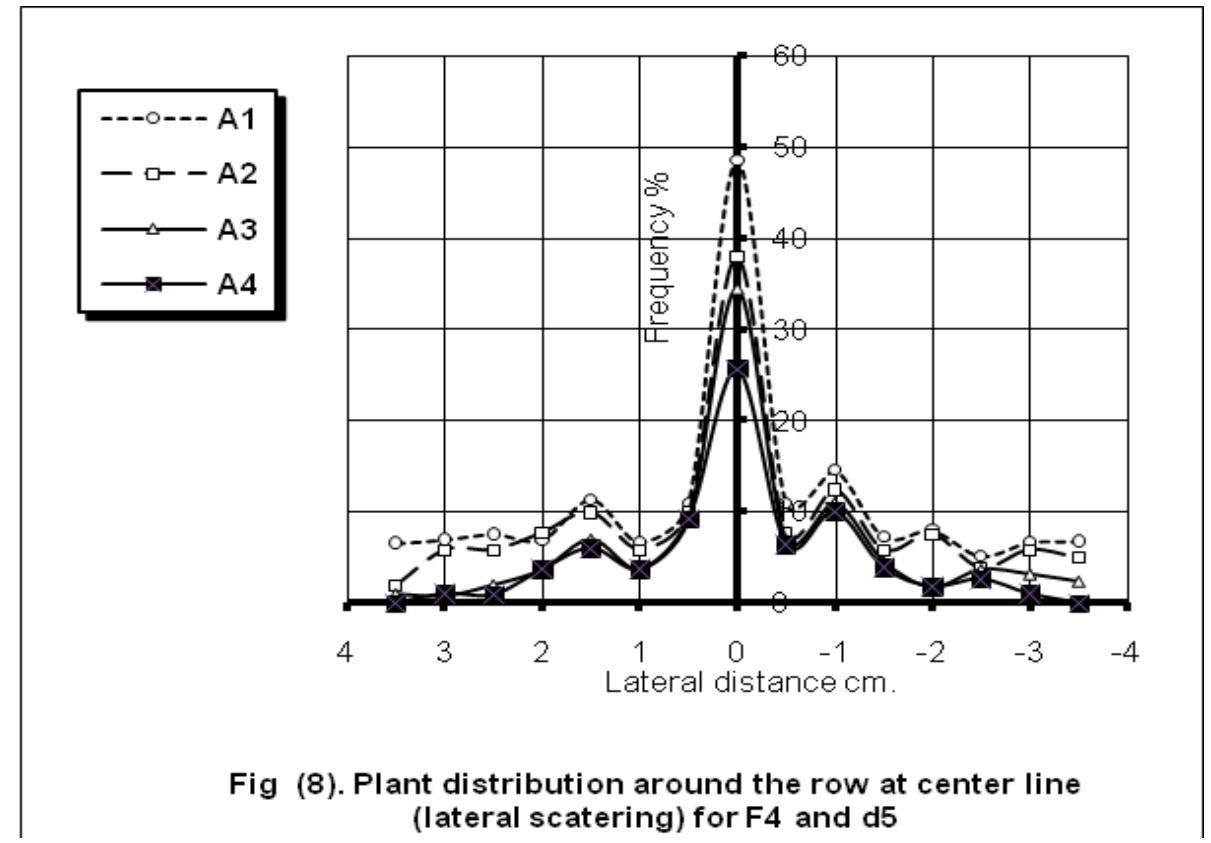

\section{Germination ratio of plants $(\%)$}

As graphically plotted in figs $(9,10,11$ and 12), one can noticed that, the highest germination ratio achieved at the lowest forward speed of $\left(\mathrm{F}_{1}\right.$ $=3 \mathrm{~km} / \mathrm{h})$ and the highest depth of furrow $\left(\mathrm{d}_{4}=5 \mathrm{~cm}\right)$ for the furrow 
opener with $50^{\circ}$ angle of ridge. At the same time, the lowest germination ratio obtained at the highest tractor forward speed $\left(\mathrm{F}_{4}=3 \mathrm{~km} / \mathrm{h}\right)$ and the shallow depth of furrow $\left(\mathrm{d}_{1}=2 \mathrm{~cm}\right)$ for the furrow opener with $20^{\circ}$ angle of ridge. One can see that, the germination ratio has a direct proportional with planting depth, angle of ridge. On the other hand the germination ratio has an indirect proportional with tractor forward speed. This may be due to increasing tractor forward speed caused not accuracy of planting depth, some scattering of corn seeds that resulting leak planting ratio and vice versa at increasing depth and angle of ridge.

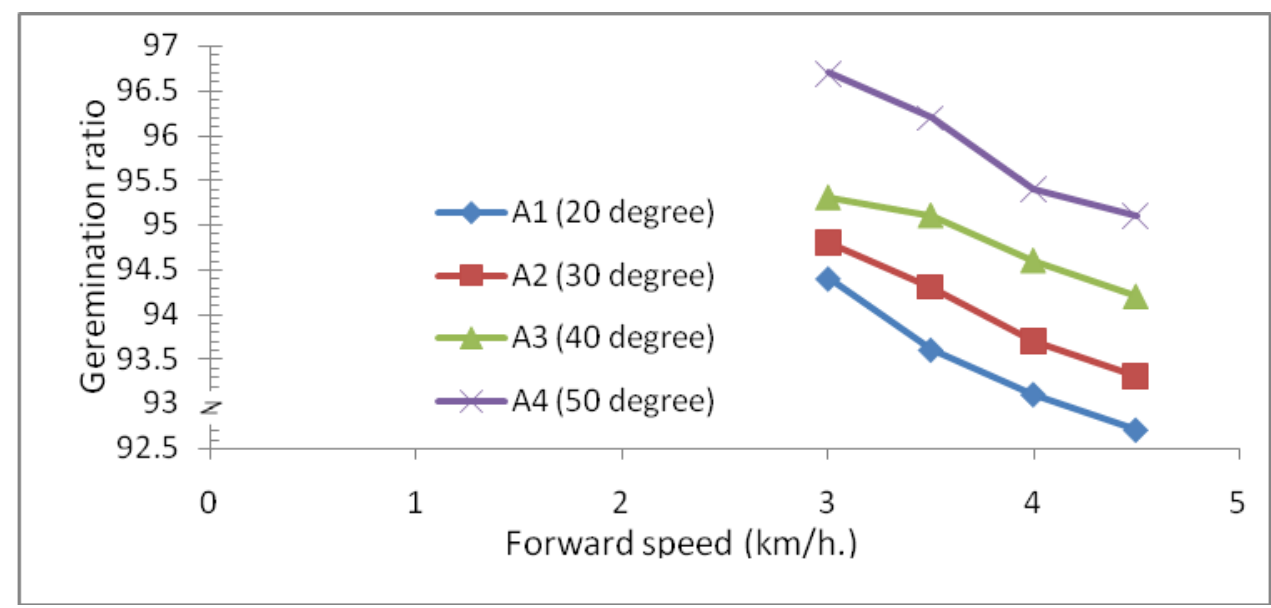

Fig. (9) Germination ratio at different forward speed, angles of ridge and planting depth $2 \mathrm{~cm}$.

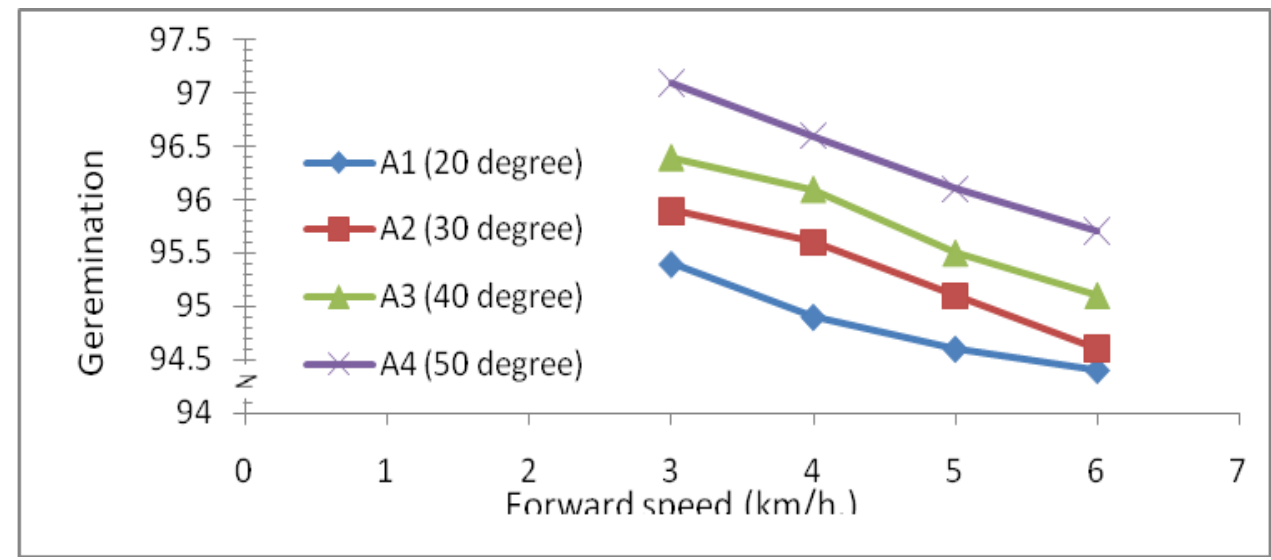

Fig.(10) Germination ratio at different forward speed, angles of ridge and planting depth $3 \mathrm{~cm}$. 


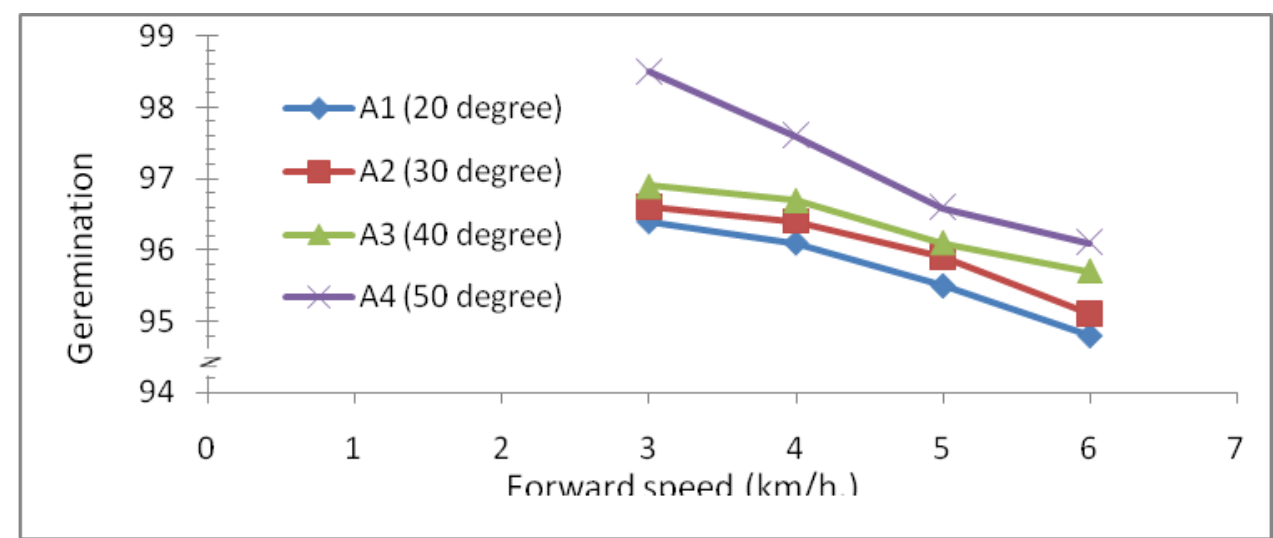

Fig. (11) Germination ratios at different forward speed, angles of ridge and planting depth $4 \mathrm{~cm}$.

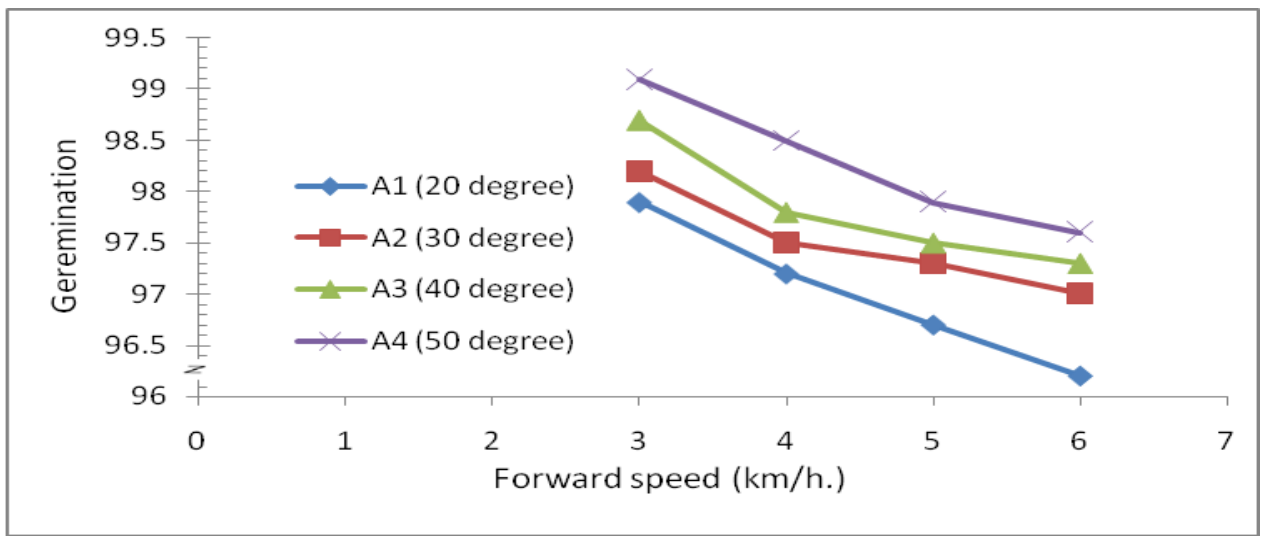

Fig. (12) Germination ratio at different forward speed, angles of ridge and planting depth $5 \mathrm{~cm}$.

\section{SUMMARY AND CONCLUSION}

The problem of soil collapsing behind furrow opener of the planters in the furrow bottom, caused the seed depths more dissimilarity which caused unadjusted germination and reduced the germination ratio of plants. To prevent this phenomenon, a new planter furrow openers were developed, with four different angles.

\section{The obtained results are summarized under two heads:}

\section{Preliminary experiments:}

The results of preliminary experiments indicated the possibility of reaching suitable planting depth by one of the developed furrow openers under study due to the angle of ridge and depth of planting. 


\section{Field experiments:}

Experiments were carried out during planting zea-maize seeds by using four developed furrow opener under study and the obtained results could be summarized as follows:

1- Increasing planting speed caused increasing in collapsed soil height, and increasing also in lateral scattering of seeds, and decreasing germination ratio of plants.

2- The furrow opener $\left(50^{\circ}\right.$ angle of ridge) showed the lowest value of the turned soil in the furrow bottom, while the furrow opener $\left(20^{\circ}\right.$ angle of ridge) caused the highest turned soil in the furrow bottom. On the other hand, the lowest seeds lateral scattering was recorded during using furrow opener $\left(50^{\circ}\right.$ angle of ridge), and the furrow opener $\left(20^{\circ}\right.$ angle of ridge) recorded the highest seeds lateral scattering.

3- Increasing the height of furrow opener wings caused a decrease in the collapsed soil height in the furrow bottom, and led to decreasing in seeds scattering around the row center line (lateral scattering).

4- Increasing depth of planting causes more fixed furrow structure, and little turned soil on the furrow bottom, which causes regular sowing depth and higher germination ratio of plants.

5- The results showed that the highest germination ratio of plants (99.1\%) was recorded at the lowest forward speed $(3 \mathrm{~km} / \mathrm{h})$, and the highest depth of planting $\left(\mathrm{d}_{4}=5 \mathrm{~cm}\right.$.) for furrow opener ( $50^{\circ}$ angle of ridge), while the lowest germination plants ratio (92.7\%) was gained at the highest planting speed of $(4.5 \mathrm{~km} / \mathrm{h})$ and the lowest depth of planting $\left(\mathrm{d}_{1}=2 \mathrm{~cm}\right.$.) for furrow opener $\left(20^{\circ}\right.$ angle of ridge $)$.

\section{REFERENCES}

Abd-Alla, H. EL. (1999), "Performance evaluation of a developed planter furrow opener". Misr J. Ag. Eng., 16(2): 176- 192.

Abo Habaga, M. M. (1990), "comparative studies on three chisel plough share - forma.” Misr J. Ag. Eng. , 7(4) : 378 - 383.

Karayel , D. and Ozmerzi , A. (2006), "Comparison of vertical and lateral seed distribution of furrow openers using a new criterion". Soil and Tillage Research Volume 95, Issues 1-2, September 2007, pp. 69-75. 
Karayel , D. (2009), "Performance of a modified precision vacuum seeder for no-till sowing of maize and soybean". Soil and Tillage Research Volume 104, Issue 1, June 2009, Pages 121-125.

Sanchez-Giron, V., Ramírez, J. J. , Litago, J. J. and Hernanz, J.L. (2004), "Effect of soil compaction and water content on the resulting forces acting on three seed drill furrow openers". Soil and Tillage Research Volume 81, Issue 1, March 2005, 25-37.

Vamerali , T. Bertocco, M. and Sartori , L. (2005), "Effects of a new wide-sweep opener for no-till planter on seed zone properties and root establishment in maize (Zea mays, L.): A comparison with double-disk opener." Soil and Tillage Research Volume 89, Issue 2, September 2006, 196-209.

\section{الملخص العربيى}

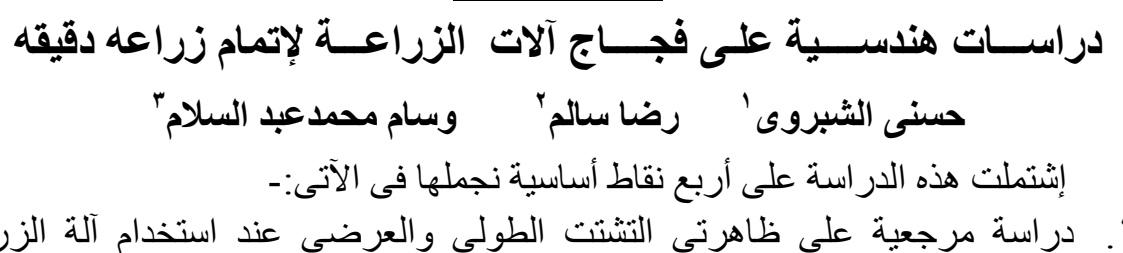

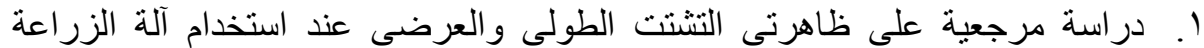
وتأثير ذلك على نسبة إنبات البذور .

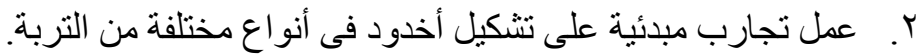

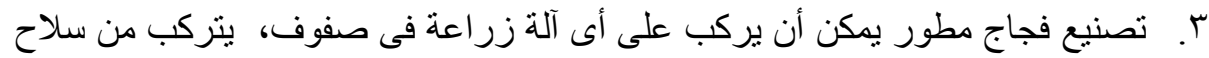

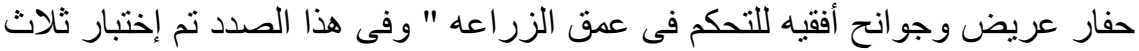
إرتفاعات لهذه الجو انح للوصول الته الته الارتفاع الأمثل" .

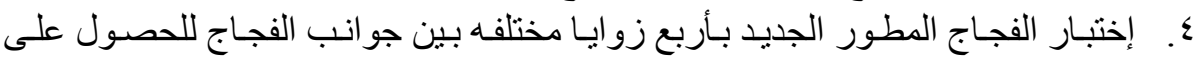

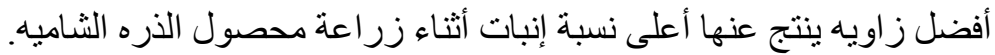

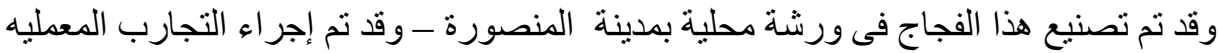

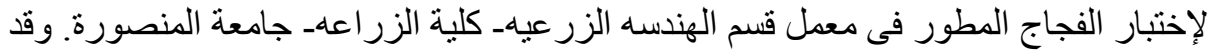
تمت التجارب الحقليه بمزر عهد خاصه بشركة لحاء للتجارة و الإستثمار الزر اعى جرئ جرف حسين-

إثنتملت الدر اسة على ثلاثة متغير ات أساسية تم إختبار ها حسب إمكانية الدر اسة المتاحة

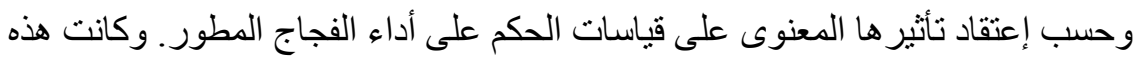

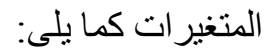

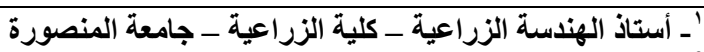

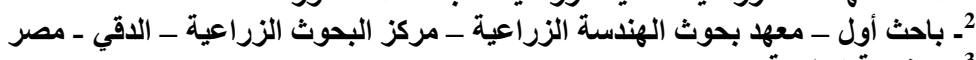

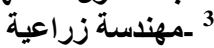



تم إختبار أربعة مستويات لسر عة التقدم أثناء الزر اعةد، وكارة أنت مستويات سر عة التقدم

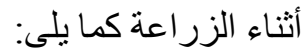

$(F 1=3 K m / h-F 2=3.5 K m / h-F 3=4 K m / h-F 4=4.5 K m / h)$

$$
\begin{aligned}
& \text { (Y) الزاويه بين جوانب الفجاج المطور: }
\end{aligned}
$$

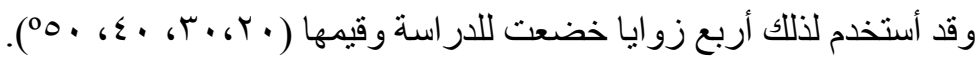

$\left(d_{1}=r \& d 2=3 \& d 3=4 \& d 4=5 \mathrm{Cm}\right)$

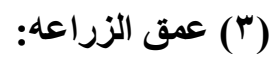

لقد تم استخدام اربع اعماق للزئ اعهر اعه وهى

ا ـ تعبين قطاع الفج بإستخدام جهاز قياس القطاع ( profile meter ) المصنع بدويا -

القياسLات: وأيضا تم حساب مساحة المقطع الناشىى فئ.

r ـ تقدير إرتفاع التربة المنهارة (المرتدة) فى الفج وتم حسابها كنسبة مئوية من العمق

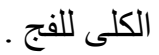

$$
\begin{aligned}
& \text { r- قياس النتتت العرضى للبذور حول مركز خط الزراعة . }
\end{aligned}
$$

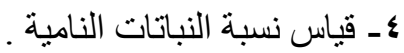

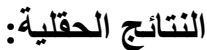

ا ـ الزاويه بين جو انب الفجاج لها تأثير و اضح على شكل مقطع الأخدود الناتج حيث

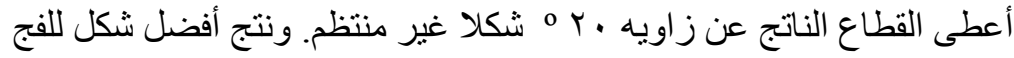
عند إستعمال الز اويه ـ0 o عند سر عة تقدم ب كم/ س وذللك عند عمقه سم .

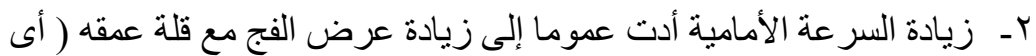

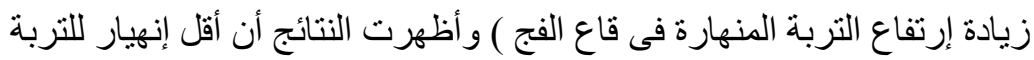

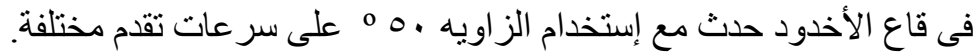

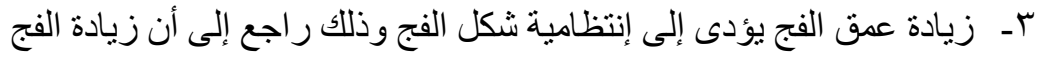
يؤدى إلى تثبيت أكبر لجوانب الفج وبالتالى تقليل إرتفاع التربة المنهارة.

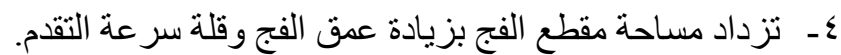

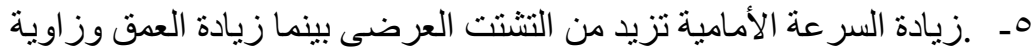
مشكل الخط تقلل من التشتت العرضهى.

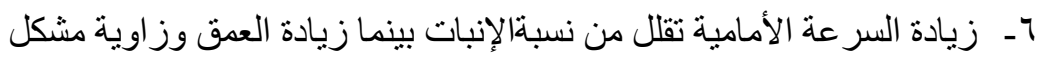
الخط ز ادت من نسية الإنبات. 